$94(440)$

\title{
V-11 前立腺癗に対する腹腔鏡下リンパ飭郭清術の検討
}

小牧市民 ${ }^{2)}$, 社会保険中京 ${ }^{2)}$, 市立岡崎 ${ }^{3)}$, 名古屋記念 4)

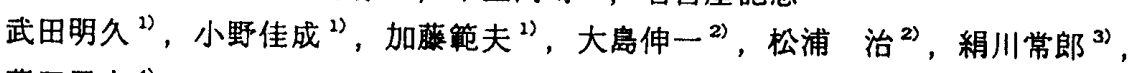
藤田民夫 ${ }^{4}$

【目的】前立腺病に対して腹腔鏡下リンバ節郭清術を行い，有用性および安全性について検封した。 【対象および方法】1992年4月から1994年7月までの2年4ヶ月間に，組織学的に前立線症と診断され，臨 床的に前立腺全摘除術の適応と考えられた症例，すなわち原則的に年齢75歳以下，PSI 以下で術前診断 がstageC以下であった症例を対象とした。39例に対して本術式を施行したが，その年龄は52歳から75 歳 (平均68歳)，術前診断はstageA2 6例，stageB 22例，stageC 11例であった。手術は全身麻酔下に 载石位で行い，操作孔は4箇所（墕上，恥骨上3横指，McBurney 点とその対称の位置）に設置した。郭 清は両側の閉鎖リンパ節に対して施行し，術中迅速凍結標本を作成して転移の有無を確認した。転移㓌 性症例に対しては引き続いて前立腺全摘除術を行った。また，1994年1月以降の7例に対しては腹膜外操 作による腹腔鏡下リンパ節郭清術を施行している。【結果および考察】摘出リンバ節数は2個から33個

(平均11個) であり，引き続き前立腺全摘除術を行った31例での残存リンバ節数は0個から33個（平均7 個）であった。リンバ節転移は13例（33\%）に見られたが，stageA2 の6例には全く認めなかった。手術 時間は経腹膜操作では86分から320分（平均164分），腹膜外操作では83分から195分（平均134分）であ り，合併症として腸管損伤が経腹膜操作の1例で見られた。前立腺癌のstaging において，腹膜外操作 による腹腔鏡下リンパ節郭清術は，手術時間が短く腸管損傷の危険も小さくてすむより侵軗の少ない術 式であると思われた。また，stageA2 の症例に対してはリンパ節郭清術を省いてもよい可能性が示唆さ れた。

\section{V-12 肢㬴外アプローチによる腹腔鏡下骨盤リンパ節垶清}

（透明スリーブを用いた直視下腰膜外剥離術）

信州大泌尿器科"、同第 1 外科2)

三沢一道"、北見好宏"、渡辺健二"、小川秋實"、林 賢"

前立腺癌に対する腹腔鏡下stagingリンパ節郭清は、近年急速に普及しつつある。しかし、腹㓐内操作で あるため、術中の腸管損伤や術後の腸管癒着の可能性があり、また腸管や腈勒带が視野の妨げとなって、 その圧排に難淽することもある。最近、バルーン拡張による腹膜外剥離を施行し、腹膜外アプローチでリ ンパ節を郭清する術式が報告されている。しかし、この手技では腹膜外の剥離は盲目的操作であり、血管 損伤等の危険性がある。そこでわれわれは、透明スリーブを用いた直視下腹膜外剥離術を施行し、良好な 結果を得たので報告する。

【対象】66藏、男性。術前stage A2の前立腺癌患者。

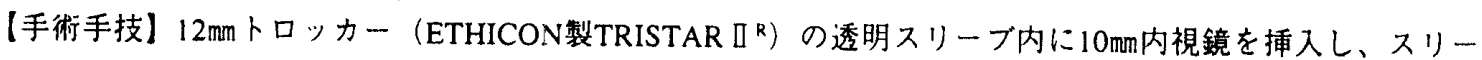
ブ先端より $1 \mathrm{~cm}$ 内側に固定する。腈直下の切開創からスリーブを腹直筋・腹膜間に㨂入し、直視下に腹膜 と腹直筋を剥離したのち、恥骨上 3 横指と㨊・恥骨中点の両側腹直筋外縁に $12 \mathrm{~mm}$ トロッカーを挿入し、鉗 子操作による腹膜の剥離を追加した後、左右の閉鎖節及び外腸骨リンパ節を郭清した。

【結果】透明スリーブによる剥離は視野が良好であり、腹膜外秒の展開は容易であった。右側では鼠径へル ニアがあり、精巣血管を剥離した後にヘルニア壤を結禁離断した。迅速病理診断でリンパ節転移のないこ とを確認し、恥骨後式根治的前立腺全摘除術を施行した。リンパ節郭清に要した時間は2時間55分で、出血 は少量であった。最大的O2は $43 \mathrm{mmHg}$ であり、合併症は皮下気腫のみであった。

【結語】透明スリーブを用いた直視下腹膜外剥離術併用、腹膜外アプローチ腹胿鏡下骨盤リンパ節郭清は安 全かつ有用な手技と考えられた。 